\title{
Characterization of Biochar from Different Sources of Plant Communities
}

\author{
K.M. Sellamuthu ${ }^{1 *}$, S. Suryia ${ }^{1}$, V.P. Duraisami ${ }^{1}$, \\ R. Mahendran ${ }^{2}$ and P. Venkatachalam ${ }^{2}$ \\ ${ }^{1}$ Department of Soil Science and Agricultural Chemistry, Directorate of Natural Resource \\ Management, TNAU, Coimbatore-3, Tamil Nadu, India \\ ${ }^{2}$ Department of Bioenergy, Agriculture Engineering College and Research Institute, TNAU, \\ Coimbatore-3, Tamil Nadu, India \\ *Corresponding author
}

\section{A B S T R A C T}

Biochar, a stable form of carbon, is produced from pyrolysis of biological materials. It is attracting growing interest because of its potential to improve soil nutrients status, increase

\section{Keywords}

Biochar, Pyrolysis,

Wood biomass,

Characterisation

Article Info

Accepted:

10 February 2018

Available Online:

10 March 2018 crop yield and sequester carbon (C) in the soil. The carbon in the biomass is subjected to easy degradation since they contain low grade carbon. But in biochar, pyrogenic carbon is formed by pyrolysis. Hence they remain in the soil for long periods. Biochar is produced from the pyrolysis of a variety of biological materials viz., Lantana camara, Dodonia viscosa, Eichornia crassipes, Prosopis juliflora, Melia dubia, Giricidia sepium and Delonix elata in pyrolysis-unit. The biochars differed much in their characteristics. Recovery of biochar was high in Prosopis whereas Eichornia showed its superiority over others in providing high pore space and water holding capacity, higher CEC, total N, P, K, $\mathrm{S}$ and micro nutrients. The microscopic analysis confirmed that plants species contain nutrients and it differs among the plant species. Considering the higher recovery and its distribution, resource of Prosopis can be harnessed. Due to the wide variations noticed among the plant species, characterisation of biochar from each plant species becomes a pre requisite before mass production for agriculture purpose.

\section{Introduction}

Biochar is finely ground charcoal which offers an extremely high surface area to support microbiota and increase nutrient availability for plants (Winsley, 2007). Marked impacts of low charcoal additions $\left(0.5 \mathrm{t} \mathrm{ha}^{-1}\right)$ on various crop species were noticed, but inhibition at higher rates (Glaser et al., 2001). Positive yield effects from biochar addition were reported by Kimetu et al., (2008) who were able to establish that the impact were in part due to non-nutrient improvement to soil function. Understanding the link between biochar function and its interactions with nutrients and crop roots may enable fertilizer use efficiency to be improved. Biochar additions to soil have the potential to alter soil microbial populations and to shift functional groups (Pietikeinen et al., 2000). Biochar retains nutrients for plant uptake and soil fertility. The infiltration of harmful quantities of nutrients and pesticides into ground water and soil erosion runoff into surface waters can 
be limited with the use of biochar (Lehmann, 2007). The carbon and nutrient dynamics in soil affected due to biochar incorporation may have a significant role in the reduction of GHGs (particularly $\mathrm{CO}_{2}$ and $\mathrm{N}_{2} \mathrm{O}$ ) emission from soil. Characterizing different sources of biochar could pave the way for its potential use and its impact on natural ecosystem. Possibly the wastes and obnoxious weeds can also be used as feed stock to prepare biochar. Hence the study was taken up to characterize biochar from different plant species and its effect on crop growth and soil properties.

\section{Materials and Methods}

Biochar samples were prepared from the pyrolysis of seven wood biomass samples viz., Lantana camara, Dodonia viscosa, Eichornia crassipes, Prosopis juliflora, Melia dubia, Giricidia sepium and Delonix elata. All the wood biomass was collected from Forest College and Research Institute, Mettupalayam, Coimbatore District. Eichornia was collected from the Kurichi lake, Coimbatore. Plant species with hard wood were chopped to $5 \mathrm{~cm}$ pieces and dried. Eichornia plants were washed with water and chopped into small pieces and dried. Moisture content of the plant species was estimated.

The pyrolysis unit consisting of a cylindrical drum made up of zinc alloy sheet which consists of combustion chamber, ventilation cone, outer tin and lid. The combustion chamber was filled with $10 \mathrm{~kg}$ chopped pieces of plant species into a mini biochar unit. Already prepared char and kerosene were used as a fire starter. The lid was made to air tight after the fire was started burning. The temperature was kept around $500 \mathrm{C}$ for 24 hours. Initial and final weight was recorded for each species. The completion of process was noted from the flame colour of yellow to blue with little smoke which implied that there was a complete burnt of the fuel. At the end of the process all the biomass was turned into char. Biochar material were taken out, cooled and ground in a wiley mill to a size of $<0.5 \mathrm{~mm}$ which was taken for all physical and chemical analysis. Biochar derived from the selected plant species were characterized for its physical properties viz., bulk density, particle density, porosity, moisture holding capacity and available moisture and chemical properties viz., electrical conductivity (EC), $\mathrm{pH}$, Cation Exchange Capacity (CEC), carbon, hydrogen, total nutrients viz., nitrogen, phosphorous, potassium, sulphur and micro nutrients viz., $\mathrm{Fe}, \mathrm{Zn}, \mathrm{Cu}$ and $\mathrm{Mn}$ as per standard procedures (Jackson, 1973). Biochar samples were subjected to FTIR and scanning electron microscopic analysis.

\section{Results and Discussion}

For characterisation studies of biochar, $<0.50$ $\mathrm{mm}$ size biochar samples were taken for analysis. Recovery of biochar from each source was calculated and it varied from 26 to 40 per cent and the highest in Prosopis sp.

\section{Physical properties}

Among the biochar from different plant species tested, physical properties like water holding capacity and pore space are in the order of Eichornia>Melia>Prosopis $>$ Delonix $=$ Lantana $>$ Gliricidia $>$ Dodonia. Water holding capacity and pore space ranged from 23.9-44.9 $\%$ and $50-84.6 \%$ respectively on air dry basis. Eichornia showed its superiority over others (Table 1).

\section{Chemical properties}

The results of chemical properties revealed that Eichornia $s p$ recorded the highest CEC of $23.8 \mathrm{c} \mathrm{mol}(\mathrm{p}+) \mathrm{kg}^{-1}$ while the least was accounted by Dodonia sp. (13.8 c mol (p+) $\left.\mathrm{kg}^{-1}\right)$. 


\section{Microscopic studies on biochar}

a. Scanning electron mic roscopic view and composition of biochar sample from Lantana
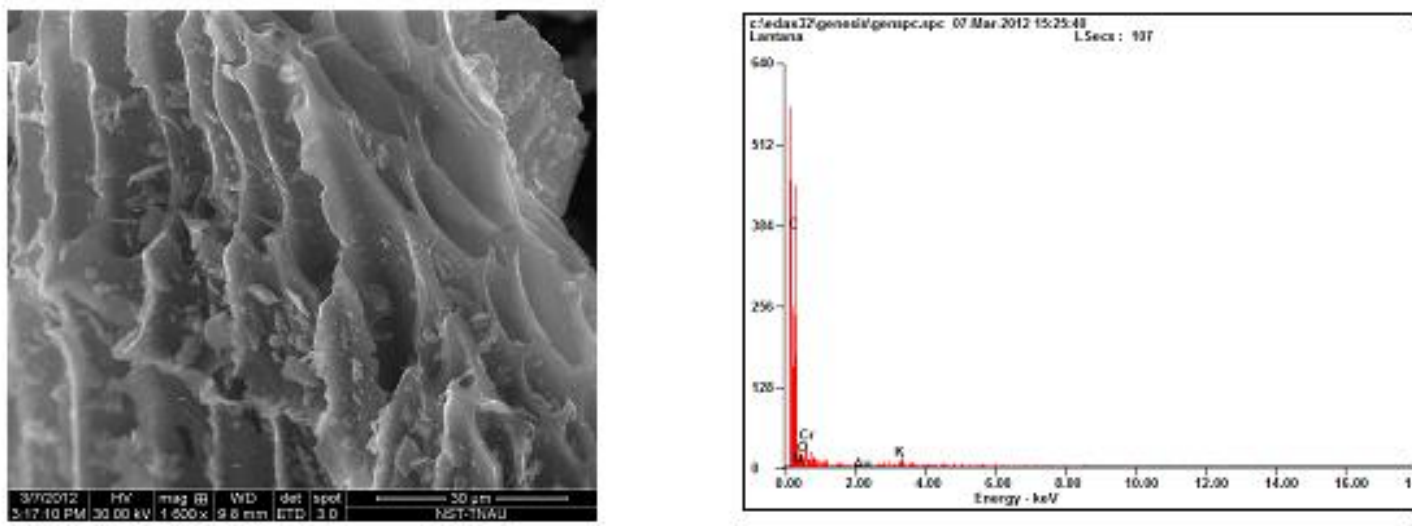

b. Scanning electron microscopic view and composition of biochar sample from D od onia
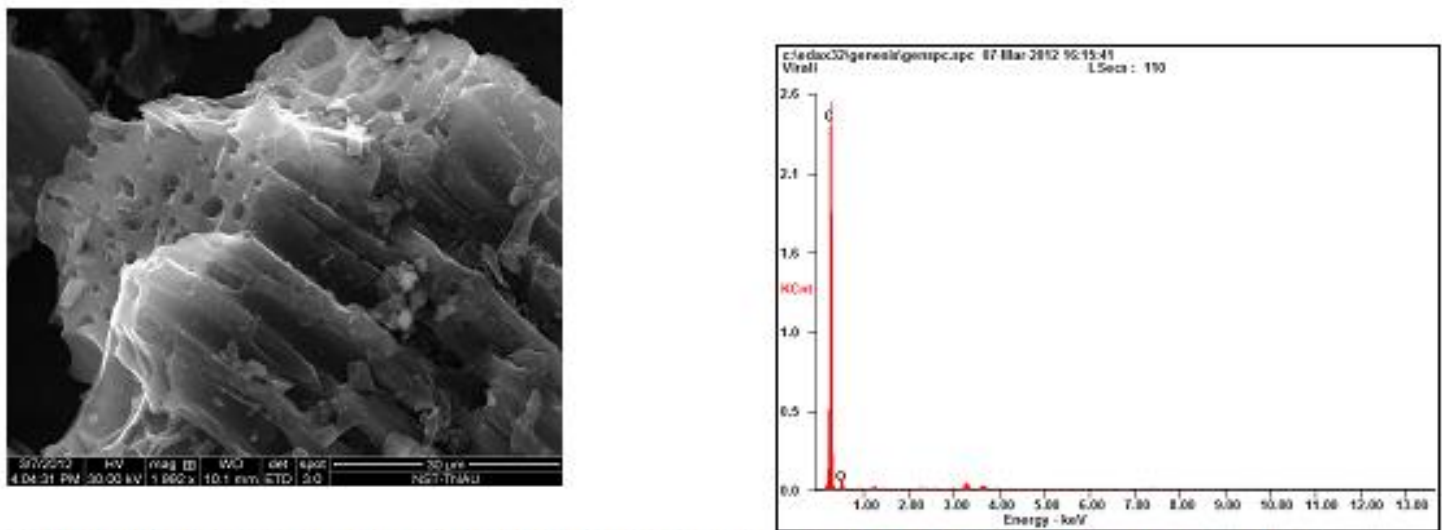

c. Scanning electron mic roscopic view and compositi on of bioch ar sample from E ichornia
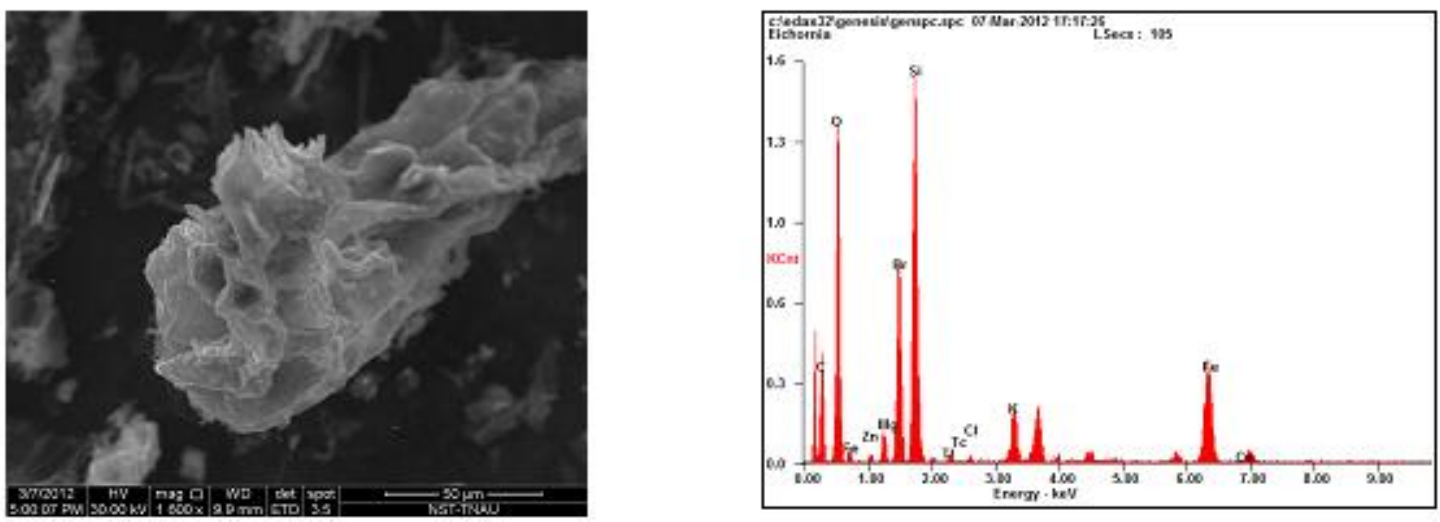
d. Scanning electron microscopic view and composition of biochar sample from Prosopis
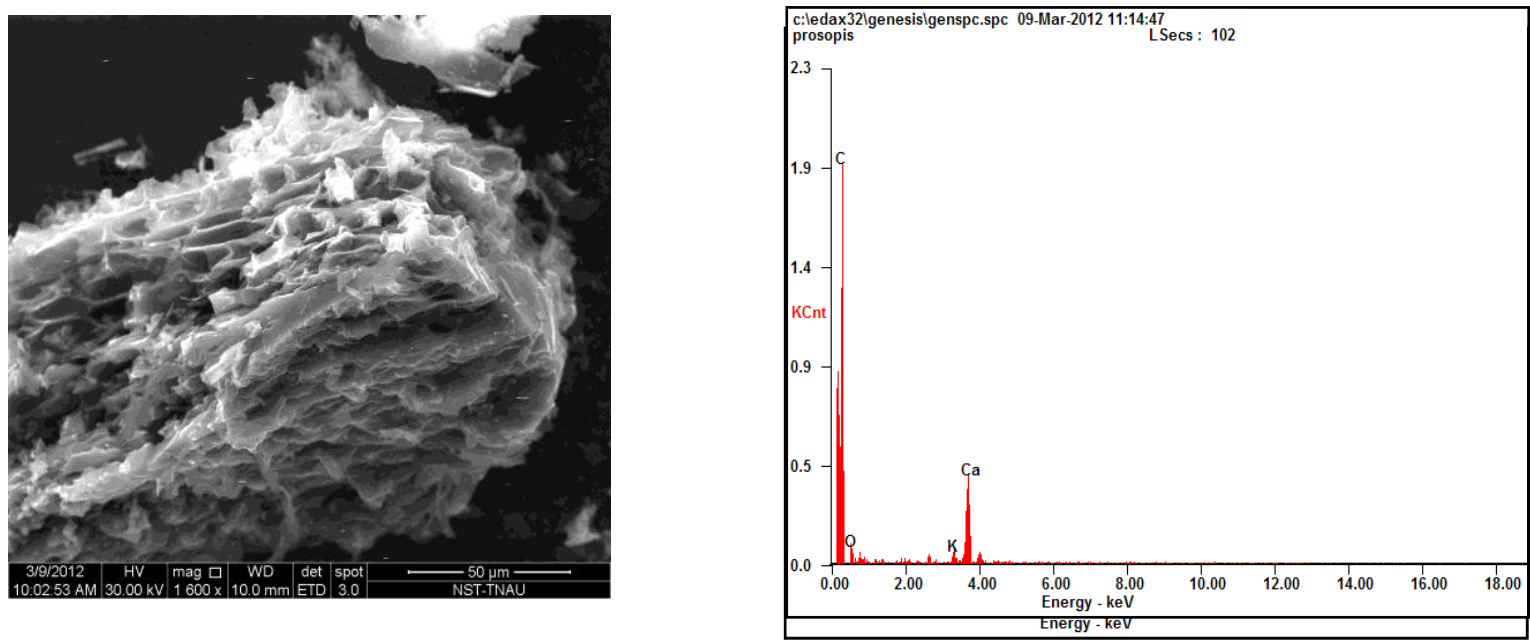

e. Scanning electron microscopic view and composition of biochar sample from Melia
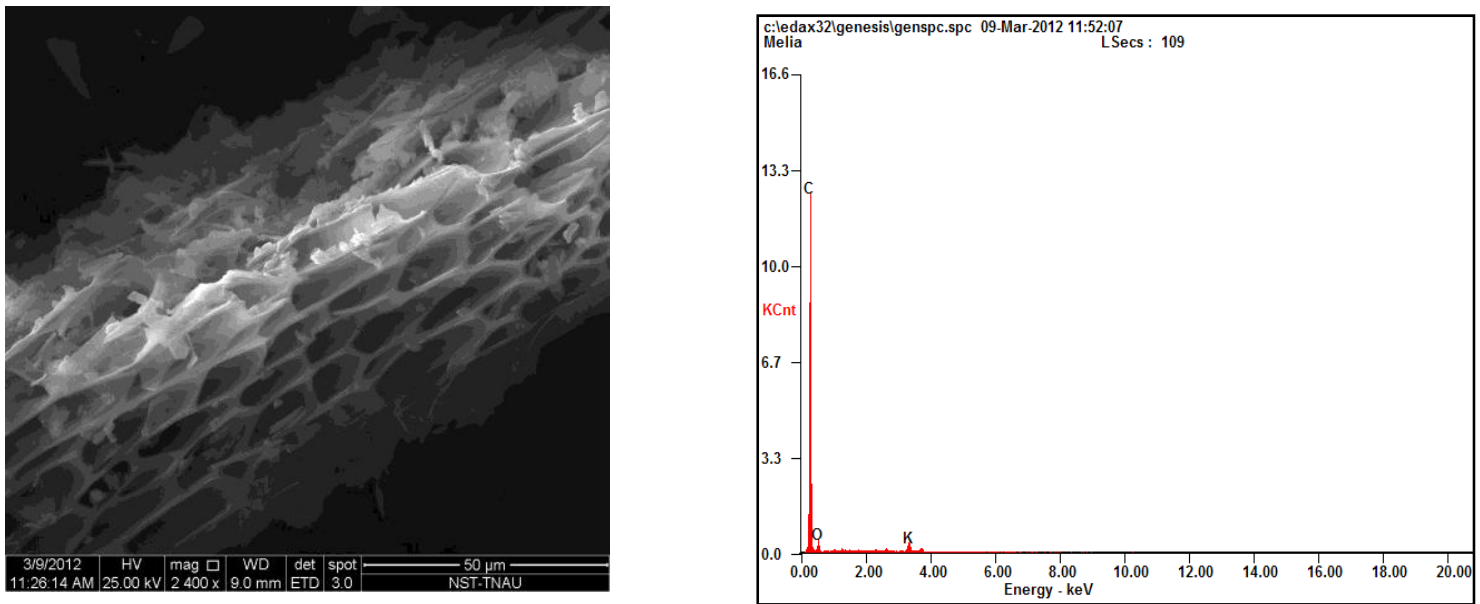

6. Scanning electron microscopic view and composition of biochar sample from Gliricidia
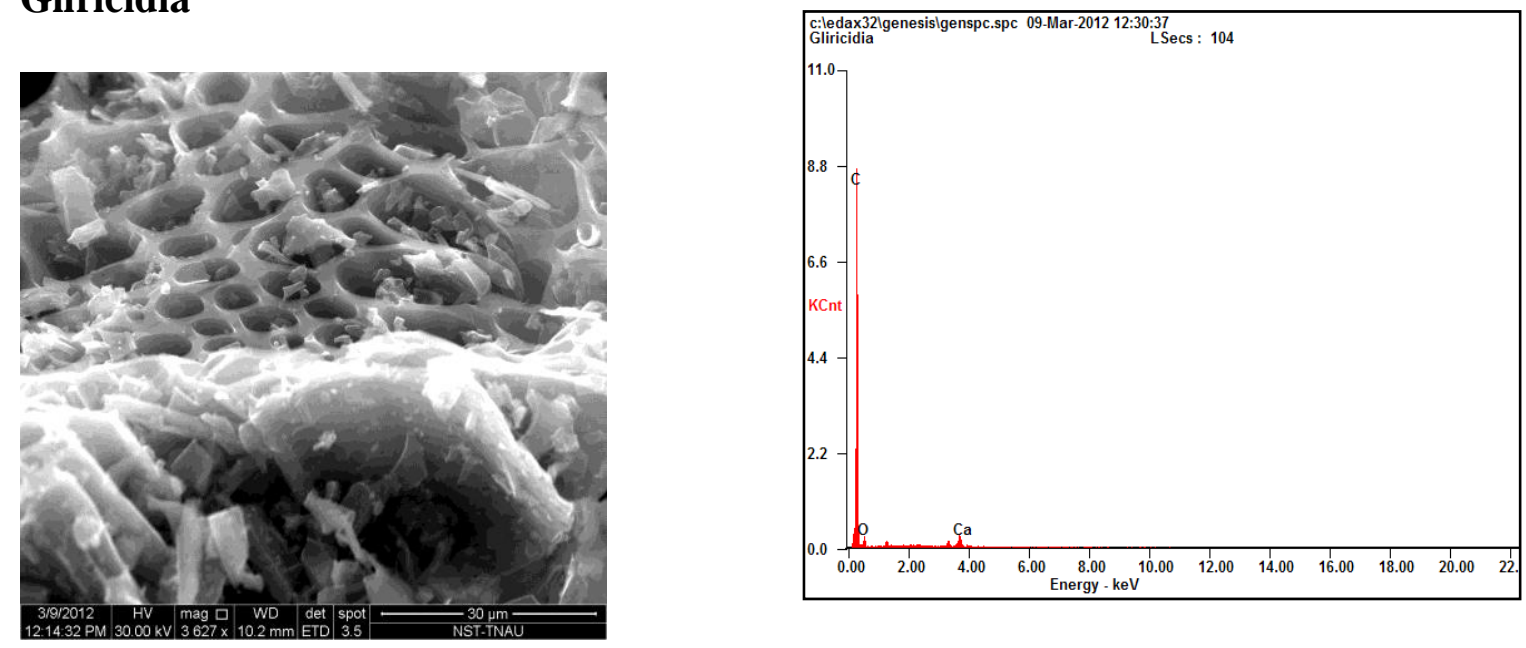


\section{f. Scanning electron microscopic view and composition of biochar sample from Delonix}
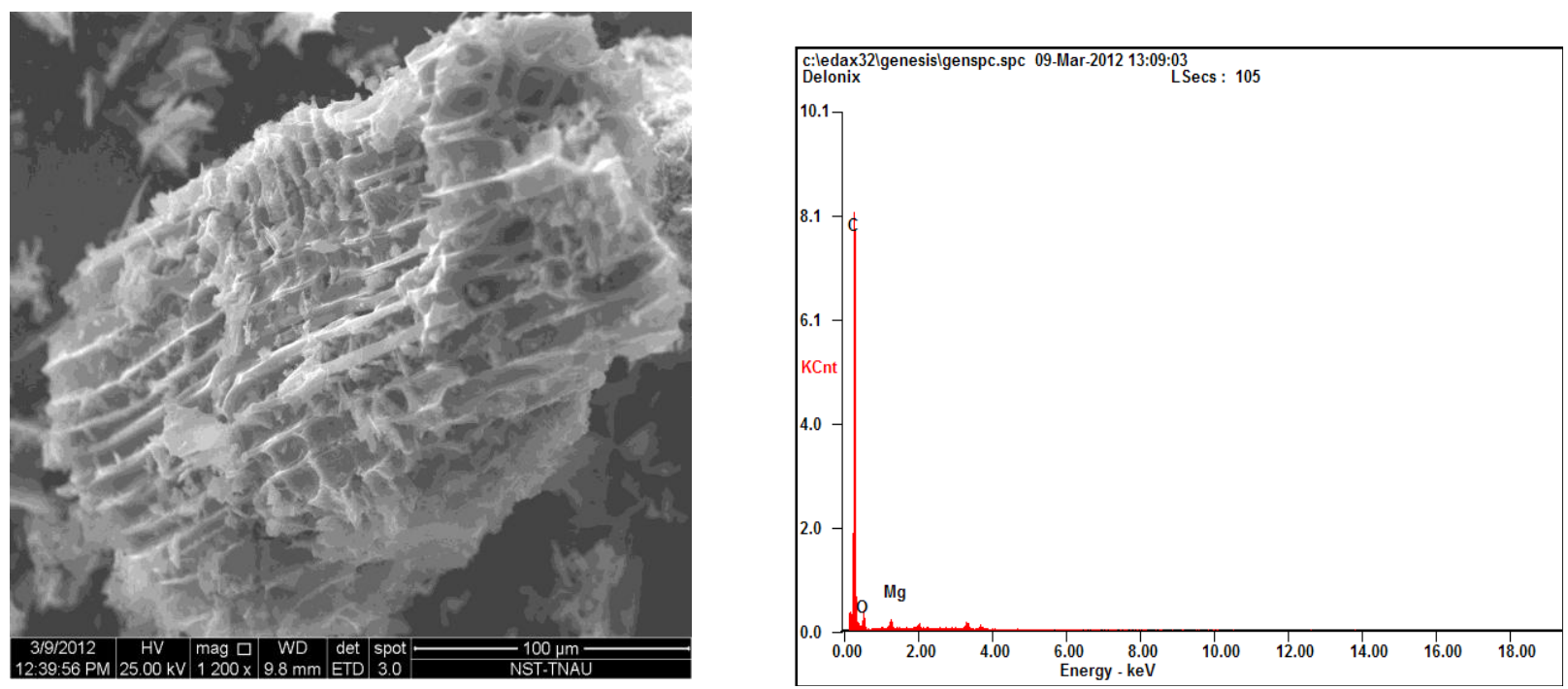

Table.1 Physical properties of biochar $(<0.50 \mathrm{~mm}$ size $)$ from different plant species

\begin{tabular}{|c|l|c|c|c|c|c|c|c|}
\hline S.No. & Biochar & $\begin{array}{c}\text { Recovery } \\
(\%)\end{array}$ & $\begin{array}{c}\text { Bulk } \\
\text { density } \\
\left(\mathrm{Mg} \mathrm{m}^{-3}\right)\end{array}$ & $\begin{array}{c}\text { Particle } \\
\text { density } \\
\left(\mathrm{Mg} \mathrm{m}^{-3}\right)\end{array}$ & $\begin{array}{c}\text { Pore } \\
\text { space } \\
(\%)\end{array}$ & $\begin{array}{c}\text { Moisture } \\
\text { content } \\
\text { at } 1 / 3 \\
\text { atm }(\%)\end{array}$ & $\begin{array}{c}\text { Moisture } \\
\text { content } \\
\text { at } 15 \\
\text { atm }(\%)\end{array}$ & $\begin{array}{c}\text { Available } \\
\text { Moisture } \\
(\%)\end{array}$ \\
\hline 1 & Lantana & 28.5 & 0.37 & 1.25 & 70.37 & 60.8 & 21.9 & 38.9 \\
\hline 2 & Dodonia & 26.1 & 0.50 & 1.00 & 50.00 & 46.0 & 22.1 & 23.9 \\
\hline 3 & Eichornia & 35.6 & 0.38 & 2.50 & 84.62 & 65.8 & 23.8 & 42.0 \\
\hline 4 & Prosopis & 40.0 & 0.36 & 1.25 & 71.43 & 64.0 & 20.7 & 43.3 \\
\hline 5 & Melia & 35.0 & 0.42 & 1.67 & 75.00 & 65.6 & 20.8 & 44.9 \\
\hline 7 & Gliricidia & 30.8 & 0.42 & 1.00 & 58.33 & 60.6 & 20.8 & 39.7 \\
\hline
\end{tabular}

Table.2 Chemical properties of biochar $(<0.50 \mathrm{~mm}$ size $)$ from different plant species

\begin{tabular}{|r|l|c|c|c|c|c|c|c|c|c|}
\hline S.No. & Biochar & $\begin{array}{c}\text { EC } \\
\mathrm{dS} / \mathrm{m} \\
(1: 5)\end{array}$ & $\begin{array}{c}\mathrm{pH} \\
(1: 5)\end{array}$ & $\begin{array}{c}\text { CEC } \\
(\mathrm{cmol} \\
(\mathrm{p}+) /\end{array}$ & $\begin{array}{c}\text { Total } \\
\mathrm{C}\end{array}$ & $\begin{array}{c}\text { Total } \\
(\%)^{*}\end{array}$ & $\begin{array}{c}\text { Total } \\
(\%)^{*}\end{array}$ & $\begin{array}{c}\text { Total } \\
(\%)^{*}\end{array}$ & $\begin{array}{c}\text { Total P } \\
(\%)^{*}\end{array}$ & $\begin{array}{c}\text { Total K } \\
(\%)\end{array}$ \\
\hline 1 & Lantana & 4.07 & 10.20 & 18.0 & 78.66 & 0.835 & 0.923 & 0.516 & 0.390 & 1.797 \\
\hline 2 & Dodonia & 1.50 & 9.10 & 13.8 & 84.25 & 0.817 & 0.426 & 0.315 & 0.100 & 0.194 \\
\hline 3 & Eichornia & 7.50 & 10.38 & 23.8 & 37.69 & 0.802 & 1.421 & 0.671 & 0.872 & 3.096 \\
\hline 4 & Prosopis & 3.03 & 9.80 & 18.8 & 80.6 & 0.772 & 1.02 & 0.371 & 0.160 & 1.226 \\
\hline 5 & Melia & 2.93 & 9.94 & 23.0 & 74.99 & 0.880 & 0.848 & 0.314 & 0.199 & 1.670 \\
\hline 6 & Gliricidia & 3.30 & 10.13 & 16.0 & 75.23 & 0.849 & 1.188 & 0.278 & 0.048 & 0.625 \\
\hline 7 & Delonix & 1.98 & 8.47 & 17.5 & 79.02 & 0.779 & 0.91 & 0.237 & 0.511 & 1.597 \\
\hline
\end{tabular}

*Analysed in CHNS analyzer, CECRI, Karaikudi 
Table.3 Micronutrient content of biochar ( $<0.50 \mathrm{~mm}$ size $)$ from different plant species

\begin{tabular}{|c|l|c|c|c|c|}
\hline S.No. & Biochar & $\begin{array}{c}\mathrm{Zn} \\
\left(\mu \mathrm{g} \mathrm{g}^{-1}\right)\end{array}$ & $\begin{array}{c}\mathrm{Fe} \\
\left(\mu \mathrm{g} \mathrm{g}^{-1}\right)\end{array}$ & $\begin{array}{c}\mathrm{Cu} \\
\left(\mu \mathrm{g} \mathrm{g}^{-1}\right)\end{array}$ & $\begin{array}{c}\mathrm{Mn} \\
\left(\mu \mathrm{g} \mathrm{g}^{-1}\right)\end{array}$ \\
\hline 1. & Lantana & 33.9 & 760.0 & 21.2 & 79.2 \\
\hline 2. & Dodonia & 13.4 & 418.5 & 13.4 & 46.1 \\
\hline 3. & Eichornia & 85.5 & 5089.0 & 20.2 & 449.3 \\
\hline 4. & Prosopis & 14.4 & 526.3 & 19.1 & 39.6 \\
\hline 5. & Melia & 24.7 & 3246.8 & 25.0 & 188.0 \\
\hline 6. & Gliricidia & 30.0 & 728.7 & 12.4 & 37.9 \\
\hline 7. & Delonix & 48.7 & 350.2 & 18.1 & 44.7 \\
\hline
\end{tabular}

Table.4 Atomic composition of biochar samples derived from plants species through scanning electron microscope

\begin{tabular}{|c|c|c|c|c|c|c|c|c|c|c|c|c|c|c|}
\hline \multirow[t]{2}{*}{ Element } & \multicolumn{2}{|c|}{ Eichornia } & \multicolumn{2}{|c|}{ Lantana } & \multicolumn{2}{|c|}{ Prosopis } & \multicolumn{2}{|c|}{ Melia } & \multicolumn{2}{|c|}{ Delonix } & \multicolumn{2}{|c|}{ Gliricida } & \multicolumn{2}{|c|}{ Dodonia } \\
\hline & $\begin{array}{c}\text { WT } \\
\%\end{array}$ & At $\%$ & $\begin{array}{c}\text { WT } \\
\%\end{array}$ & At $\%$ & $\begin{array}{c}\text { WT } \\
\%\end{array}$ & At $\%$ & $\begin{array}{c}\text { WT } \\
\%\end{array}$ & At $\%$ & $\begin{array}{c}\text { WT } \\
\%\end{array}$ & At $\%$ & $\begin{array}{c}\text { WT } \\
\%\end{array}$ & $\begin{array}{c}\text { At } \\
\%\end{array}$ & $\begin{array}{c}\text { WT } \\
\%\end{array}$ & At $\%$ \\
\hline$C K$ & 35.2 & 50.49 & 70.45 & 83.5 & 87.19 & 92.2 & 92.3 & 94.4 & 91.3 & 93.5 & 93 & 95 & 96.19 & 97.1 \\
\hline$O K$ & 34.9 & 37.58 & 1.66 & 1.48 & 7.74 & 6.14 & 7.13 & 5.47 & 8.1 & 6.23 & 6.1 & 4.7 & 3.81 & 2.88 \\
\hline$Z n L$ & 0.71 & 0.19 & - & - & - & - & - & - & - & - & - & - & - & - \\
\hline$M g K$ & 0.91 & 0.64 & - & - & - & - & - & - & - & - & - & - & - & - \\
\hline$B r L$ & 10.4 & 2.23 & - & - & - & - & - & - & - & - & - & - & - & - \\
\hline $\mathrm{SiK}$ & 10.7 & 6.55 & - & - & - & - & - & - & - & - & - & - & - & - \\
\hline$T l M$ & 0.53 & 0.04 & - & - & - & - & - & - & - & - & - & - & - & - \\
\hline$C l K$ & 0.09 & 0.04 & - & - & - & - & - & - & - & - & - & - & - & - \\
\hline$K K$ & 1.42 & 0.63 & 0.41 & 0.15 & 0.58 & 0.19 & 0.56 & 0.18 & - & - & - & - & - & - \\
\hline $\mathrm{FeK}$ & 5.06 & 1.56 & - & - & - & - & - & - & - & - & - & - & - & - \\
\hline $\mathrm{CoK}$ & 0.16 & 0.05 & - & - & - & - & - & - & - & - & - & - & - & - \\
\hline$N K$ & - & - & 9.84 & 10 & - & - & - & - & - & - & - & - & - & - \\
\hline$C r L$ & - & - & 17.64 & 4.83 & - & - & - & - & - & - & - & - & - & - \\
\hline$A u M$ & - & - & 0 & 0 & - & - & - & - & - & - & - & - & - & - \\
\hline $\mathrm{CaK}$ & - & - & - & - & 4.49 & 1.42 & & & & & & & & \\
\hline$M g K$ & - & - & - & - & - & - & - & - & 0.6 & 0.3 & 0.8 & 0.3 & - & - \\
\hline
\end{tabular}

Maximum total carbon was found in Dodonia $s p$. The order of carbon content was Dodonia $>$ Prosopis > Delonix > Lantana > Gliricidia > Melia >Eichornia. Biochar samples were digested with acid and the total nutrient contents were estimated. Chemical composition of biochar was analysed using CHNS analyzer at Central Electro Chemicla Research Institute, Karaikudi. The results for CHNS are furnished in Table 4. Highest amount of total N, P, K and S was found in Eichornia sp. (Table 2) The highest total $\mathrm{N}$
(1.42\%), P (0.87\%), K (3.09 \%), S (0.671\%) were recorded in Eichornia sp. Total micronutrient content revealed that Eichornia $s p$. found to exhibit high $\mathrm{Zn}, \mathrm{Fe}$ and $\mathrm{Mn}$ whereas the $\mathrm{Cu}$ content was found to be higher $\left(25.0 \mu \mathrm{g} \mathrm{g}^{-1}\right)$ in Melia sp. as compared to other species (Table 3 ).

\section{Microscopic studies on biochar}

Microscopic analysis of biochar confirmed the results from CHNS analyzer. Total weight 
of carbon from individual particle was taken into account for interpretation. High carbon was found in Dodonia followed by Gliricidia, Melia, Delonix, Prosopis, Lantana, and Eichornia. Eichornia contains variety of metals. Lantana found to accumulate chromium. Calcium and potassium found in Prosopis sp. Magnesium was noticed in Delonix sp. and Gliricidia sp.

A better utilization of residues from charcoal production itself provides opportunities for a combination with a biochar soil management system (Lehman et al., 2006). Biochar has been widely applied in tree nurseries and is a recommended amendment (Jaenicke, 1999). It is used for propagation, in some cases due to its ability to adsorb inhibitory substances (Nhut et al., 2001). The particle size of the biochar appears to play a minor role in its effect on soil fertility and crop production (Lehmann et al., 2003), which simplifies the application of the technology.

Recovery of biochar was high in Prosopis sp @ $40 \%$. Eichornia sp showed its superiority over others in providing high pore space and water holding capacity. Eichornia sp recorded the higher CEC, total $\mathrm{N}, \mathrm{P}, \mathrm{K}, \mathrm{S}$ and micro nutrients. The highest organic carbon was found in Dodonia sp. Also the microscopic analysis confirmed that plants species contain nutrients and it differs among the plant species.

Though Eichornia $s p$ found to be the good choice, its availability and accumulation of heavy metals pose a threat to continuous application of biochar from Eichornia sp. Considering the higher recovery and its distribution, resource of Prosopis $s p$ can be harnessed. It can be concluded that nature and properties of biochar varies with the sources of biomass prepared. Hence, before mass production of biochar, characteristics of the individual source have to be studied and utilised for agriculture purpose.

\section{Acknowledgment}

The authors sincerely acknowledge Government of Tamil Nadu for the financial support in Part II plan scheme.

\section{References}

Glaser, B., J. Lehmann and J. Zech. 2002. Ameliorating physical and chemical properties of highly weathered soils in the tropics with charcoal $-\mathrm{A}$ review. Biol. Fert. Soil. 35: 219-230

Jackson, M.L. 1973. Soil chemical analysis. Prentice Hall of India Private Limited, New Delhi. p.496.

Jaenicke, H. 1999. Good Tree Nursing Practices: Practical Guidelines for Research Nurseries, International Centre for Research in Agroforestry, Nairobi.

Kimetu, J.M., Lehmann, J., Ngoze, S. O., Mugendi, D. N., Kinyangi, J. M., Riha, S., Verchot, L., Recha, J. W., and Pell, A. N., 2008. Reversibility of soil productivity decline with organic matter of differing quality along a degradation gradient. Ecosystems 11(5): 726-739.

Lehmann, J., D.C. Kern, B. Glaser and W. I. Woods. 2003. Biochar and carbon sequestration. In: Amazonian Dark Earths: Origin, Properties, Management. Kluwer Academic Publishers, Netherlands, pp. 523.

Lehmann, J., Gaunt, J., Rondon, M., 2006. Bio-char sequestration in terrestrial ecosystems - a review. Mitigation and Adaptation Strategies for Global Change, 11, 395-419.

Lehmann, J. 2007. A handful of carbon. Nature, 447, 143-144.

Nhut, D.T., B.V. Le, S. Fukai, M. Tanaka and K.T.T. Van. 2001. Effects of activated charcoal, explant size, explant position and sucrose concentration on plant and shoot regeneration of Lilium 
longiflorum via young stem culture, Plant Growth Regul., 33, 59-65.

Pietikeinen, J., Kiikkil, O. and Fritze, H. 2000. Charcoal as a habitat for microbes and its effects on the microbial community of the underlying humus, Oikos, 89, 231-242.
Shenbagavalli, S and Mahimairaja, S. 2012. Characterization and effect of biochar on nitrogen and carbon dynamics in soil. Int. J. on Advanced Biol, Res.. 2(2) 2012: 249-255

Winsley P., 2007. Biochar and Bionenergy Production for Climate Change. New Zealand Science Review 64 (1): 1-10.

\section{How to cite this article:}

Sellamuthu, K.M., S. Suryia, V.P. Duraisami, R. Mahendran and Venkatachalam, P. 2018. Characterization of Biochar from Different Sources of Plant Communities. Int.J.Curr.Microbiol.App.Sci. 7(03): 891-898. doi: https://doi.org/10.20546/ijcmas.2018.703.104 